\title{
SHORT COMMUNICATION: THE EFFECT OF TANNIN SOLUTION IN PERFORMING SUCCESFULL EGG MICROINJECTION ON AFRICAN CATFISH (Clarias gariepinus)
}

\author{
Muhammad Hunaina Fariduddin Ath-thar")\#, Komar Sumantadinata ${ }^{\star * n}$, \\ Alimuddin"), and Rudhy Gustiano") \\ ") Research Institute for Freshwater Aquaculture \\ *) Bogor Agricultural University
}

\begin{abstract}
In order to successfully perform a gene transfer activity using microinjection, an individual egg is needed. The common standard operating procedure to collect the individual egg is by applying chemical solution to remove the sticky layer covering the egg surface. Among several available solutions, tannin is one of alternative substances that can be used in performing egg microinjection on African catfish. In this study, the effect of different dosages of tannin solution to remove the sticky layer of eggs was observed. The study was conducted at the Laboratory of Fish Breeding and Genetics, Bogor Agricultural University. Prior to microinjection, the eggs were treated with different dosages of tannin solution right after fertilization. There were four different levels of dosage used as the treatments i.e.: 0.3, 0.5, 0.7, and $0.9 \mathrm{ppm}$. After the treatments, each individual egg was injected using DNA pmâactin-hrGFP plasmid with a concentration of $20 \mu \mathrm{g} / \mathrm{mL}$. The results showed that the dosage of $0.5 \mathrm{ppm}$ of tannin was the most effective treatment compared to the other dosages. This dosage produced $71.4 \%$ hatching rate and $57.1 \%$ transgenic embryos respectively.
\end{abstract}

\section{KEYWORDS: tannin, microinjection, gene, transgenic}

\section{INTRODUCTION}

The importance of transgenic fish technology in aquaculture industry is rapidly increasing. The recent development in aquaculture biotechnology is that the production of transgenic fish through gene transfer into eggs has been performed using egg microinjection. In order to successfully perform a gene transfer activity through microinjection, an individual egg is needed. However, a sticky layer of substance covering a whole egg cluster has caused a great difficulty to inject an individual egg within the cluster (Ath-thar et.al., 2008). Therefore, the available techniques to remove the egg's sticky layer have to be assessed and developed. Tannin technique is one of the techniques and can potentially and effectively be used in microinjection of African catfish eggs. However, there is limited information on research showing the relation between tannin dosage and the success of microinjection.

A novel reporter gene used in this study was GFP gene. GFP gene has a unique advantage where its detection does not require exogenously added substrate. Beside of that, the protein itself is fluorescent and can be visualized in the expressing cells upon exposure to UV light (Chalfie, 1994 in lyengar et al., 1996). One of GFP genes has been reported to have higher fluorescence intensity, more consistent and lower cytotoxicity intensity than GFPs iso-

\# Corresponding author. Research Institute for Freshwater Aquaculture. Jl Sempur No. 1, Bogor, Indonesia. Tel.: + 622518327890

E-mail address: 
lated from Aequorea victoria, which was hrGFP gene (Humanized Renilla reniformis Green Fluorescent Protein). hrGFP gene was isolated from Anthozoan soft coral Renilla reniformis (Felts et al., 2001). GFP gene can be used as a marker gene to analyze the effectiveness of a promoter (Chou et al., 2001) or can be used as a reporter gene for the investigation of tissue specific gene expression (Gong et al., 2002).

Microinjection is the most popular technique of gene transfer into fish (Hacket, 1993). According to Stuart et al. (1988) and Pandian et al. (1991) in Collas et al. (2000), egg microinjection is the most successful method of gene transfer of fish genomes. One stage cell phase is the best phase for inserting gene because all cells will be expected to contain that gene when the cell develops to the next developmental stage (Devlin, 1997). DNA concentration was also an important factor that supports a successful gene microinjection into fish egg. According to Volckaert et al. (1994), the DNA concentration used in African catfish was 20 $\mu \mathrm{g} / \mathrm{mL}$.

The objective of this study was to examine the effect of different dosages of tannin solution in performing a successful gene microinjection on African catfish (Clarias gariepinus).

\section{MATERIALS AND METHOD}

The study was conducted at the Laboratory of Fish Breeding and Genetics, Bogor Agricultural University. The DNA construct used in this study was plasmid form. These plasmids were driven by medaka $\alpha$-actin promoter ( 3.7 $\mathrm{kb}$ length fragment). The promoter used in this study was isolated from pOBA-109, made by Takagi et al. (1994) using PCR method. All of these DNA constructs were made by Sawayama (2006).

Prior to microinjection, the eggs were collected within 38 minutes of fertilization. The eggs were immediately treated with different dosages of tannin solution. There were four different levels of dosage used as the treatment, i.e: $0.3,0.5,0.7$, and $0.9 \mathrm{ppm}$. After the treatments of tannin solution, the eggs were injected using DNA pmo-actin-hrGFP plasmid with a concentration of $20 \mu \mathrm{g} / \mathrm{mL}$ into their cytoplasms prior to the second cleavage. The procedure of cytoplasmic injection was described in detail by Kinoshita \& Ozato (1995) and Collas et al. (2000).

Injected eggs were incubated in aquaria at $28^{\circ} \mathrm{C}-30^{\circ} \mathrm{C}$ post injection. Resulted embryos were then transferred into incubated aquaria at $28^{\circ} \mathrm{C}$. The embryos' developments were observed at $8,12,16,2024$ hours after injection and 4 and 8 after fertilization under a bright field microscope (Zeiss Stemi DV4).

The Hatching Rate (HR) and Percentages of Embryo Expressed Transgene (PEET) can be calculated as follows:

$$
H R=\frac{\text { hatched eggs }}{\text { survive injected embryo }} \times 100 \%
$$

$$
\text { PEET }=\frac{\text { embryo expressed transgene }}{\text { all injected embryo }} \times 100 \%
$$

The transient expression was observed under microscope equipped with a fluorescent filter (Olympus BH2-RFCA) and attached with a reflected light fluorescent attachment (Olympus BH2-RFC2). Photographs were taken using 5 MP Casio Exilim (EX-Z500).

\section{RESULT AND DISCUSSION}

The results showed that the dosage of 0.5 ppm of tannin was the most effective treatment compared to the other dosages. This dosage produced $71.4 \%$ hatching rate (Table 1).

It is already known that sticky layer on eggs have been a problem in the hatchery incuba-

Table 1. Embryo hatching rate (HR) of Clarias gariepinus

\begin{tabular}{cccc}
\hline $\begin{array}{c}\text { Tannin dosages } \\
(\mathbf{p ~ p ~} \mathbf{)})\end{array}$ & $\begin{array}{c}\text { Number of } \\
\text { eggs }\end{array}$ & $\begin{array}{c}\text { Number of } \\
\text { hatching eggs }\end{array}$ & $\begin{array}{c}\text { Hatching rate } \\
\mathbf{( \% )}\end{array}$ \\
\hline 0,3 & 35 & 20 & 57,1 \\
0,5 & 35 & 25 & 71,4 \\
0,7 & 35 & 19 & 54,3 \\
0,9 & 35 & 18 & 51,4 \\
\hline
\end{tabular}


tion of many freshwater fishes. Hence, the effort reducing the sticky layer becomes so important to increase the hatching rate (Rottmann et al., 1991).

Individual egg is needed in almost all of transfer genes using microinjection. Application of tannin substance to remove the egg's sticky layer constitutes the success of the work. There are many alternative solutions that can be use to remove the sticky layer of egg such as milk mixture (Billard, 1999), yeast for starlet, Acipencer ruthenus (Horvath et al., 2002) and pineapple juice for Cyprinus carpio (Thai \& Ngo, 2004). However, tannin solution is the most effective solution for egg microinjection of catfish family. Tannin solution contains phenolic substance (Cannas, 2006). The phenolic substance in tannin solution can effectively remove egg's sticky layer. However, the only problem is that tannin is very toxic to eggs if it contacts with egg for over than 20 seconds (Horvath et al., 2002).
Results of the experiment showed that the certain amount of tannin solution was effective in removing egg's sticky layer without reducing too much of the chorion layer. This result is of importance in microinjection activity which still needs good chorion layer to avoid damaged egg.

The observation of PEET (Table 2) shows the most effective tanine solution $(0.5 \mathrm{ppm})$ gave a better result in microinjection (57.1\%). The transient expression observation result (Figure 2) indicates that the transient expression was observed in embryos at $8,12,16,20$, and 24 hours after gene injection. The differences between the eggs successfully and unsuccessfully expressing transgene are shown on Figure $1 \mathrm{~B}$ and $1 \mathrm{C}$.

The transient expression occurred at 4 hours after the injection with very weak expression to be captured by the camera. The strongest transient expression occurred at 8

Table 2. Percentages of embryo expressed transgen (PEET) of C. gariepinus

\begin{tabular}{cccc}
\hline $\begin{array}{c}\text { Tannin dosages } \\
\text { (ppm) }\end{array}$ & $\begin{array}{c}\text { Number of } \\
\text { eggs }\end{array}$ & $\begin{array}{c}\text { Number of embryo } \\
\text { expressed transgene }\end{array}$ & $\begin{array}{c}\text { Percentages of } \\
\text { embryo expressed } \\
\text { transgene (\%) }\end{array}$ \\
\hline 0,3 & 35 & 17 & 48,6 \\
0,5 & 35 & 20 & 57,1 \\
0,7 & 35 & 15 & 42,9 \\
0,9 & 35 & 12 & 34,3 \\
\hline
\end{tabular}
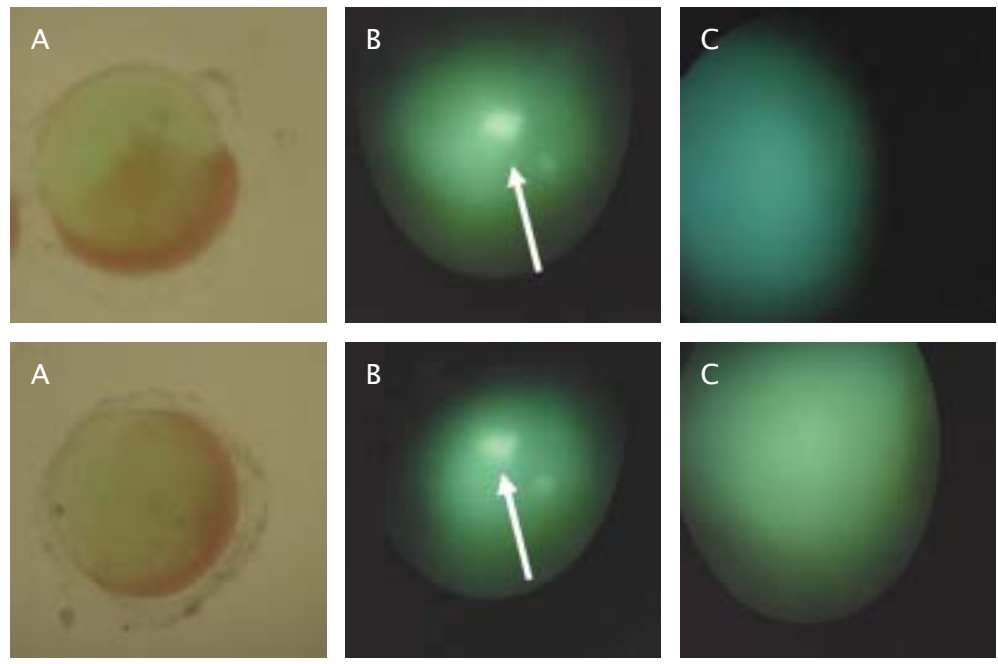

8 hour after injection

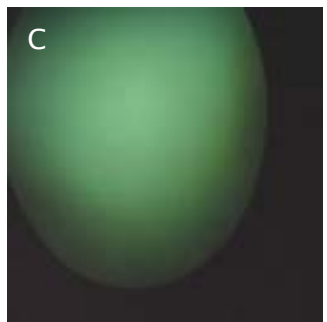

12 hour after injection 

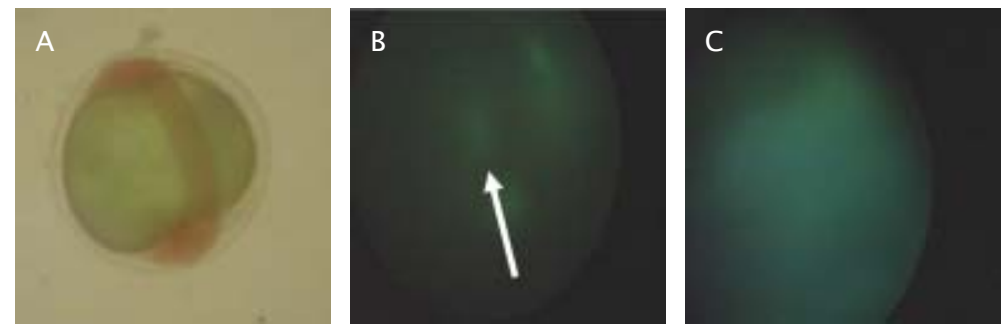

16 hour after injection
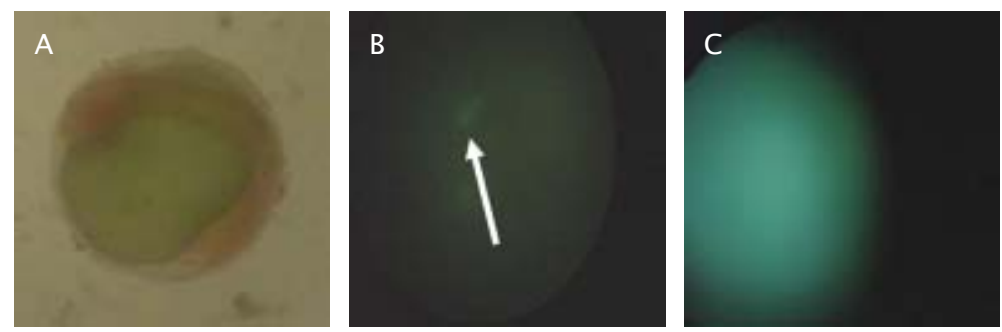

20 hour after injection
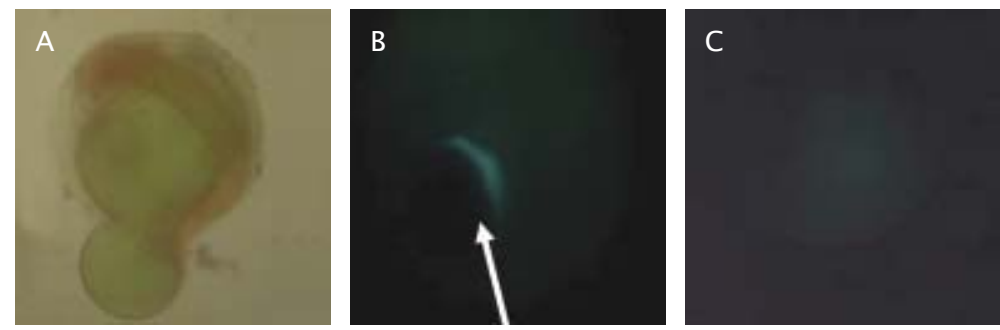

24 hour after injection
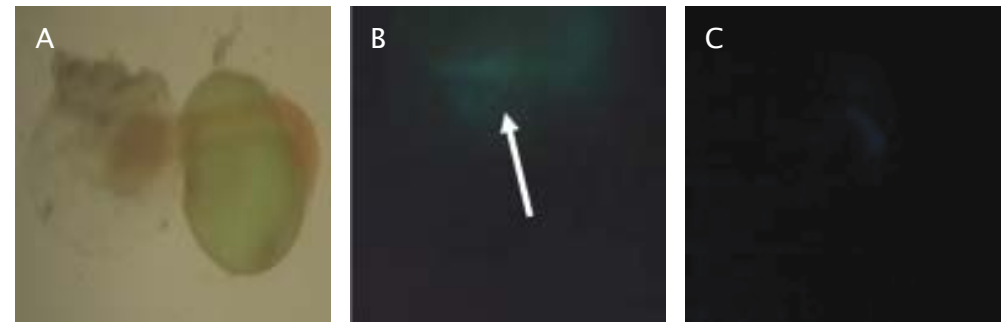

4 hour after hatching
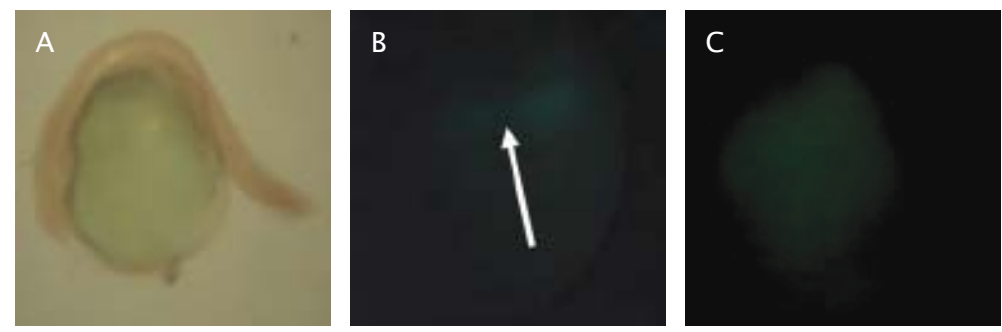

8 hour after hatching

\section{Information:}

A : Observed with backlight microscope

B : Observed with fluorescent microscope (no hrGFP gene expression)

C : Observed with fluorescent microscope (with hrGFP gene expression)

Figure 1. hrGFP (Humanized Renilla reniformis Green Fluorescent Protein) gene expression of $C$. gariepinus embryo at 8, 12, 16, 20, and 24 hours after hrGFP gene injection and 4 and 8 hours after hatching 
and 12 hours after injection. At 4 and 8 hours after fertilization the transient expression weakened and then disappeared.

\section{CONCLUSION}

The tannin dosage of $0.5 \mathrm{ppm}$ was the most effective treatment to remove sticky layer of egg to support the successful eggs microinjection on african catfish (C. gariepinus).

\section{REFFERENCE}

Ath-thar, M.H.F., Alimuddin, Sumantadinata, K., \& Gustiano, R. 2008. Efektivitas Promoter â-Actin Ikan Medaka Oryzias latipes dengan Penanda Gen hrGFP (Humanized Renilla reniformis Green Fluorescent Protein) pada Ikan Lele Clarias sp. keturunan F0. Jurnal Riset Akuakultur Indonesia. 3 (2)

Billard, R. 1999. Carp: Biology and Culture. Praxis Publishing, Cichester, UK. p. 79-90

Cannas, A. 2006. Tannins : A Definitons. Cornell Univ. Anim. Sci. Publ. USA. p. 10-13

Chou, C.Y., Horng L.S., \& Tsai, H.J. 2001 . Uniform GFP-expression in Transgenic Medaka Oryzias latipes at the F0 Generation. Transgenic Research. 10: 303-315

Collas, P., Husebeye H., \& Alestrom, P. 2000. Transferring Foreign Genes into Zebrafish Eggs by Microinjection. Transgenic Animal: Generation and Use. p. 119-122.

Devlin, R.H. 1997. Transgenic Salmonids. In : Houdebine, LM (Ed.). Transgenic Animal: Generation and Use. (pp.105-117). Harewood Academic Publishers. Amsterdam. The Netherlands. p. 105-117.

Felts, K., Rogers, B., Chen, K., Ji, H., Sorge, J., \& Vaillancourt, P. 2001. Recombinant Renilla reniformis GFP Displays Low Toxicity. Stratagenei, 13: 85-87.

Fletcher, G.L. \& Davies, P.L. 1991. Transgenic Fish for Aquaculture. Genetic Engineering, 13: 331-371.

Garcia-Pozo, S., Bejar, J., Shaw, M., \& Alvarez, M.C. 1998. Effect of Exogenous DNA microinjection on Early Development Response of the Seabream Sparus aurata. Molecular Marine Biology and Biotechnology, 7(4): 248-257
Gong, Z., Wan, H., Ju, B., He, J., Wang, X., \& Yan, T. 2002. Generation of Living Color Transgenic Fish. In: Shimizu N, Aoki T, Hirono I. and Takashima F. (eds) Aquatic Genomics: Steps Toward a Great Future. Springer-Verlag. New York. p. 329-339.

Hacket, P.B. 1993. The Molecular Biology of Transgenic Fish. In: Hocachka and Mommesen (Eds.). Biochemistry and Molecular Biology of Fishes Elsevier Science Publishers BV. 2: 21 8-221.

Horvath, L., Tamas, G., \& Seagrave, C. 2002. Carp and Pond Fish Culture, Fish News Books Blackwell Science. Oxford. UK. p2356

lyengar, A., Muller, F., \& Maclean, N. 1996. Regulation and Expression of Transgenes fish A Review. Transgenic Research 5:147-166

Kinoshita, M. \& Ozato, K. 1995. Cytoplasmic Microinjection of DNA into Fertilized medaka (Oryzias latipes) eggs. The Fish Biology Journal Medaka, 7: 59-64

Rottmann, W.R., Shireman, V.J., \& Chapman, A.F. 1991. Techniques for Taking and Fertilizing the Spawn of Fish. Southern Regional Aquaculture Center 426.

Sawayama, A. 2006. Membuat Konstruksi Vektor untuk Mendapatkan Ekspresi Gen yang Tinggi dengan Memodifikasi 3'UTR. Thesis. Tokyo University of Marine Science and Technology. Jepang. (in Japanese). p. 7-10.

Takagi, S., Sasado, G., Tamiya, G., Ozato, K., Wakamatsu, Y., Takeshita, A., \& Kimura, M. 1994. An Efficient Expression Vector for Transgenic Medaka Construction. Molecular Marine Biology and Biotechnology, 3: 192-199.

Thai, B.T. \& Ngo, T.G. 2004. Use of Pineapple Juice for Elimination of Egg Stickiness of Common Carp (Cyprinus Carpio L.). Asian Fish. Sci., 17: 159-162.

Volckaert, F.A., Hellemans, B.A., Galbusera, P., \& Ollevier, F. 1994. Replication, Expression and Fate of Foreign DNA During Embryonic and Larval Development of the African Catfish Clarias gariepinus. Molecular Marine Biology and Biotechnology, 3(2): 57-69. 